\title{
Physiological response to the action of the agrotoxic 2,4-Dichlorophenoxiacetic acid
}

\section{in Saccharomyces cerevisiae}

\author{
Resposta fisiológica da ação do agrotóxico ácido 2,4-Diclorofenoxiacético em Saccharomyces \\ cerevisiae
}

Respuesta fisiológica a la acción del ácido 2,4-Diclorofenoxiacético agrotoxico en Saccharomyces cerevisiae

Received: 08/26/2021 | Reviewed: 09/01/2021 | Accept: 09/01/2021 | Published: 09/05/2021

\author{
Debora Tavares Sarabia \\ ORCID: https://orcid.org/0000-0002-5329-7691 \\ Universidade Estadual de Mato Grosso do Sul, Brazil \\ E-mail: deborasarabia@hotmail.com \\ Larissa Pires Mueller \\ ORCID: https://orcid.org/0000-0003-0134-7033 \\ Universidade Federal da Grande Dourados, Brazil \\ E-mail: laripiresmueller@gmail.com \\ Maria do Socorro Mascarenhas Santos \\ ORCID: https://orcid.org/0000-0002-5343-4502 \\ Universidade Estadual de Mato Grosso do Sul, Brazil \\ E-mail: maria_mascarenhas@outlook.com \\ Margareth Batistote \\ ORCID: https://orcid.org/0000-0001-9865-2362 \\ Universidade Estadual de Mato Grosso do Sul, Brazil \\ E-mail: margarethbatistote@gmail.com
}

\begin{abstract}
The presence of xenobiotic compounds in the environment is responsible for impacts on the ecosystem. An example is pesticides that pose risks to non-target species, such as microorganisms present in the soil and that are responsible for cycling nutrients, some can be used to measure the effects of these compounds, such as yeasts because when exposed to toxic substances begin to present changes in physiological and genetic mechanisms. Thus, this study aims to evaluate the toxicity effect of the 2,4-D pesticide on Pedra-2 (PE-2) and Fleischmann ${ }^{\circledR}$ (FLE) yeasts. 2,4-D dilutions of 2.0; 4.0 and $6.0 \mu \mathrm{g} \mathrm{L}^{-1}$ were added to a solution prepared with $20 \mathrm{ml}$ of ultra-pure water and $2.0 \mathrm{~g}$ of sucrose where the yeasts were grown. The phenotypic profile of yeasts against the toxicity of the compound was evaluated quantitatively with cell viability. Using the methylene blue method and qualitatively with cell growth tests in Petri dishes containing 2\% YPD medium and flocculation on slides with methylene blue. Yeasts showed loss of viability and the FLE strain showed greater sensitivity, the cellular growth of this yeast was also more affected and, consequently, presented higher flocculation rates. The data show that the longer exposure time and the doses and concentrations of 2,4-D interfered with the physiological response of the FLE yeast. Thus, we can suggest that this microorganism has the potential to be considered for environmental tests and analyses as a bioindicator.
\end{abstract}

Keywords: Phenotypic profile; Toxicity; Bioindicator.

\section{Resumo}

A presença de compostos xenobióticos no meio ambiente são responsáveis por impactos ao ecossistema. Um exemplo são os agrotóxicos que representam riscos para as espécies não-alvos, como os microrganismos presentes no solo e que são responsáveis pela ciclagem dos nutrientes, alguns podem ser utilizados para mensurar os efeitos destes compostos como as leveduras, pois quando exposta a substância tóxicas passam a apresentar alterações nos mecanismos fisiológicos e genéticos. Assim, este estudo visa avaliar o efeito de toxicidade do agrotóxico 2,4-D nas leveduras Pedra-2 (PE-2) e Fleischmann® (FLE). Foram feitas diluições do 2,4-D de 2,0; 4,0 e 6,0 $\mu \mathrm{g} \mathrm{L}^{-1}$ que foram adicionadas a uma solução preparadas com $20 \mathrm{~mL}$ de água ultrapura e $2,0 \mathrm{~g}$ de sacarose onde foram crescidas as leveduras. O perfil fenotípico das leveduras frente a toxicidade do composto foi avaliado de forma quantitativa com a viabilidade celular utilizando método azul de metileno e, qualitativa com testes de crescimento celular em placas de Petri contendo meio YPD $2 \%$ e floculação em lâminas com azul de metileno. As leveduras apresentaram perda de viabilidade e a linhagem FLE mostrou maior sensibilidade, também o crescimento celular desta levedura foi mais afetado e por consequência apresentou índices mais elevados de floculação. Os dados mostram que o tempo mais prolongado de exposição e as doses mais concentrações do 2,4-D interferiram na resposta fisiológica da levedura 
FLE. Desta forma, podemos sugerir que este microrganismo apresenta um potencial a ser considerado para testes e análises ambientais como um bioindicador.

Palavras-chave: Perfil fenotípico; Toxicidade; Bioindicador.

\section{Resumen}

La presencia de compuestos xenobióticos en el medio ambiente es responsable de los impactos en el ecosistema. Un ejemplo son los pesticidas que presentan riesgos para especies no objetivo, como los microorganismos presentes en el suelo y que son responsables del ciclo de nutrientes, algunos pueden usarse para medir los efectos de estos compuestos, como las levaduras, porque cuando se exponen a sustancias tóxicas comienzan a presentar cambios en los mecanismos fisiológicos y genéticos. Así, este estudio tiene como objetivo evaluar el efecto de toxicidad del pesticida 2,4-D sobre las levaduras Pedra-2 (PE-2) y Fleischmann® (FLE). Diluciones de 2,4-D de 2,0; 4,0 y 6,0 $\mu \mathrm{g}$ $\mathrm{L}^{-1}$ que se añadieron a una solución preparada con $20 \mathrm{ml}$ de agua ultrapura y 2,0 $\mathrm{g}$ de sacarosa donde se cultivaron las levaduras. El perfil fenotípico de las levaduras frente a la toxicidad del compuesto se evaluó cuantitativamente con viabilidad celular mediante el método del azul de metileno, y cualitativamente con pruebas de crecimiento celular en placas Petri conteniendo medio YPD al $2 \%$ y floculación en portaobjetos con azul de metileno. Las levaduras mostraron pérdida de viabilidad y la cepa FLE mostró mayor sensibilidad, el crecimiento celular de esta levadura también se vio más afectado y, en consecuencia, presentó mayores tasas de floculación. Los datos muestran que el mayor tiempo de exposición y las dosis y concentraciones de 2,4-D interfirieron con la respuesta fisiológica de la levadura FLE. Por tanto, podemos sugerir que este microorganismo tiene potencial para ser considerado como bioindicador para pruebas y análisis ambientales.

Palabras clave: Perfil fenotípico; Toxicidad; Bioindicador.

\section{Introduction}

Society has been facing complex challenges such as environmental problems caused by different factors, some are related to social and environmental problems, mainly the results of anthropogenic actions as a result of the need to ensure increased food production, since there was population growth in recent decades (Noel, 2015). These factors directly influenced the relationship between the environment and man. In fact, some production processes contain a polluting load with the presence of organic contaminants that are present in the household, agro-industrial, petrochemical, pesticide, and other waste that, when discarded incorrectly, cause various harm to both health and the environment (Sisinno \& Oliveira-Filho, 2013). Among those mentioned, pesticides have a longer life cycle in nature, as they are chemical substances that persist for a long time in the environment (Carvalho, 2017).

According to Sarabia et al. (2019), in Brazil, some pesticides are among the most used, such as glyphosate; which is classified as low toxic and 2,4-D extremely toxic. These two pesticides belong to the herbicide class and use it in crops such as soybeans, corn, cotton, rice, sugarcane, coffee, wheat, among others. 2,4-D is among the most consumed in the world, as it is widely used in different cultures and pasture management, being used successively in the same area (Thomaz, 2018).

Thus, given the chemical characteristics of these pesticides such as the affinity and solubility for soil aggregates, their relative persistence can be increased representing a risk for non-target species, which can cause changes in both the environmental compartments, especially soil and water, as induce changes in the various organisms to present there (Da Silva Pinto et al., 2021). Such changes can be morphological, physiological and genetic, so some of these organisms can serve as a source of studies to detect the presence of xenobiotic substances, also providing opportunities for evaluations of the toxicity of the compounds and their effects at the cellular level (Francisco \& De Queiroz, 2018).

Some species of microorganisms can be used because they have advantages such as low cost, reduced analysis time, minimisation of waste generated during the studies, and others (Dos Santos et al., 2012). Within this context, Saccharomyces cerevisiae is promising for environmental studies, because when exposed to xenobiotic compounds, changes in physiological and genetic mechanisms are susceptible, such as gene derepression, which triggers numerous defence mechanisms concerning toxic action (Dragone et al., 2015). One of the physiological responses is the activation of the flocculation mechanism with a view to its survival (Moreno-García et al., 2018). 
Thus, studies using microorganisms to measure the toxicity of a given compound or pesticide can serve as a powerful tool of environmental interest and, depending on the detection sensitivity, can be used to monitor the presence of xenobiotic compounds in the environment. Thus, this study aims to evaluate the toxicity action of 2,4-Dichlorophenoxyacetic acid pesticide on Saccharomyces cerevisiae Pedra-2 (PE-2) and Fleischmann® (FLE) yeasts.

\section{Methodology}

\subsection{Preparation of Pesticide Solutions}

The pesticide 2,4-Dichlorophenoxyacetic acid (2,4-D) with a purity standard of $99 \%$ was used. Solutions were prepared from a stock solution of $100 \mathrm{mg} \mathrm{L}^{-1}$ and the compound diluted in the proportion of $1 \mathrm{~mL}$ in $99 \mathrm{~mL}$ of methanol to obtain a final concentration of $1000 \mu \mathrm{g} \mathrm{L}^{-1}$ with a final volume of $100 \mathrm{~mL}$. The solution was kept in an amber bottle and stored at a low temperature $\left(-18^{\circ} \mathrm{C}\right)$.

\subsection{Microorganism used}

The microorganisms used in this study were the Pedra-2 and Fleischmann® strains available at the Biotechnology, Biochemistry and Biotransformation laboratory of the Center for Studies in Natural Resources-CERNA.

\subsection{Evaluation of the phenotypic toxicity profile}

\subsubsection{Cell viability test}

For the analysis of cell viability, $0.1 \mathrm{~g}$ of freeze-dried yeasts were added to Erlenmeyer flasks containing $20 \mathrm{~mL}$ of ultra-pure water and $2.0 \mathrm{~g}$ of sucrose, to which concentrations of $\left(2.0 ; 4.0\right.$ and $\left.6.0 \mu \mathrm{g} \mathrm{L}^{-1}\right)$ of the 2,4-D pesticide prepared from the stock solution. The flasks were incubated at $30^{\circ} \mathrm{C}$ at times of 30,60 and 90 minutes. $10 \mu \mathrm{L}$ aliquots were collected and added to Eppendorf's containing $90 \mu \mathrm{L}$ of the methylene blue dye and counted in a Neubauer chamber (Lee, Robinson \& Wang, 1981). The experiments were carried out in triplicate, and the results were analysed with GraphPad Prisma 7.

\subsubsection{Cell growth test}

Yeasts were grown in the presence of a 2,4-D pesticide at concentrations $\left(2.0,4.0\right.$ and $\left.6.0 \mu \mathrm{g} \mathrm{L}^{-1}\right)$, at a temperature of $30{ }^{\circ} \mathrm{C}$ at times of 30, 60 and 90 minutes. After the incubation period, $5 \mu$ aliquots of the samples were dropped onto sterile plates containing the solid medium YPD $2 \%$ and incubated at $30{ }^{\circ} \mathrm{C}$ for 72 hours. The samples were analysed through the growth profile qualitatively through observation and image recording. Growth and inhibition criteria by comparison were used and classified into: (+) growth, (++) mild inhibition, (+++) moderate inhibition, (++++) severe inhibition.

\subsubsection{Flocculation Test}

For the flocculation test, $0.1 \mathrm{~g}$ of the freeze-dried yeasts were grown in Erlenmeyer flasks containing $20 \mathrm{~mL}$ of ultrapure water and $2.0 \mathrm{~g}$ of sucrose and concentrations of $\left(2.0,4.0\right.$ and $\left.6.0 \mu \mathrm{g} \mathrm{L}^{-1}\right)$ of 2,4-D. The flasks were incubated at $30^{\circ} \mathrm{C}$ at times of 30, 60 and 90 minutes. After this period, $10 \mu \mathrm{L}$ aliquots were removed and added to Eppendorf's; containing $90 \mu \mathrm{L}$ of methylene blue dye and kept at rest for $20 \mathrm{~min}$. Soon after, slides were prepared with $5 \mu \mathrm{L}$ of the samples; and (with the aid of an optical microscope) the phenotypic alteration with the presence of flakes was observed. Analyses were performed qualitatively with records through images.

\subsection{Graphical summary of the study development stages.}

A graphic summary was prepared with the stages of development of the study (Figure 1). 
Figure 1. Stages of study development.

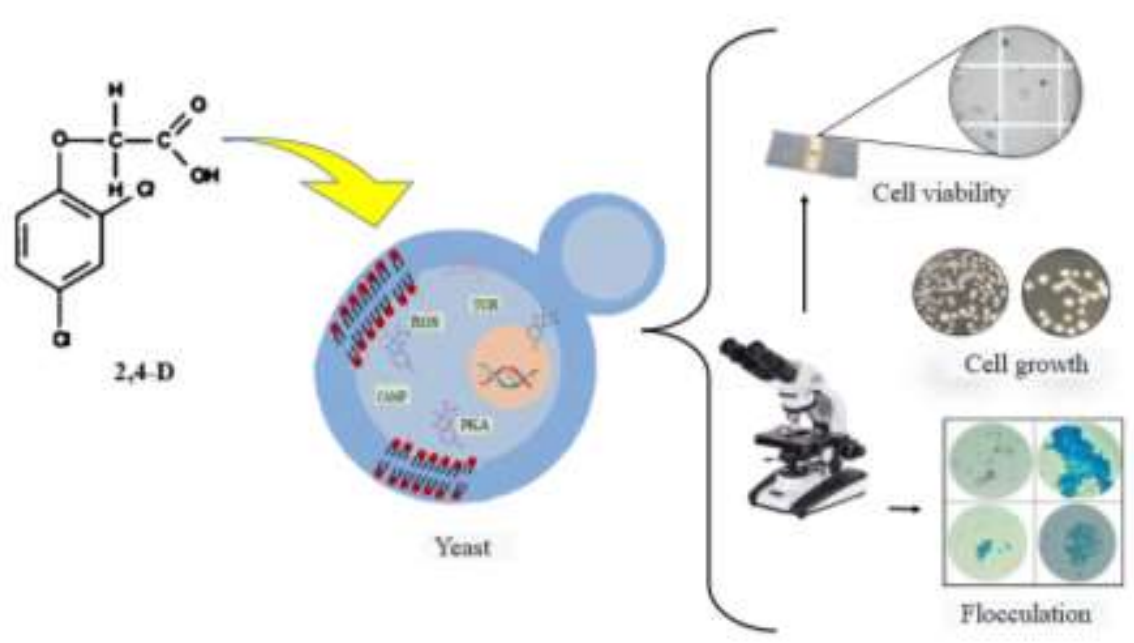

Source: Authors.

\section{Results and Discussion}

In the evaluation of the cellular viability of the PE-2 and FLE yeasts, a gradual drop in the viability rate can be observed for both strains both as a function of the exposure time and the analyzed concentrations of the pesticide. The data suggest that the FLE yeast is more susceptible to the toxic action of 2,4-D and that possibly the physiological mechanisms of this yeast were affected since it presented lower rates of viability. This fact may be related to the characteristics of the yeast itself, as it is a strain widely used in the bakery industry. On the other hand, PE-2 proved to be more resistant to the action of pesticides (Figure 2).

This strain is used in fermentation processes for ethanol production in Brazilian mills. According to Lopes et al. (2016), yeast strains used in ethanol fermentation are more resistant to stress factors and have a high capacity to adapt to environmental disturbances.

Figure 2. Evaluation of cell viability of Pedra-2 and Fleischmann ${ }^{\circledR}$ yeasts at different times and concentrations of 2,4dichlorophenoxyacetic acid-2,4-D pesticide.
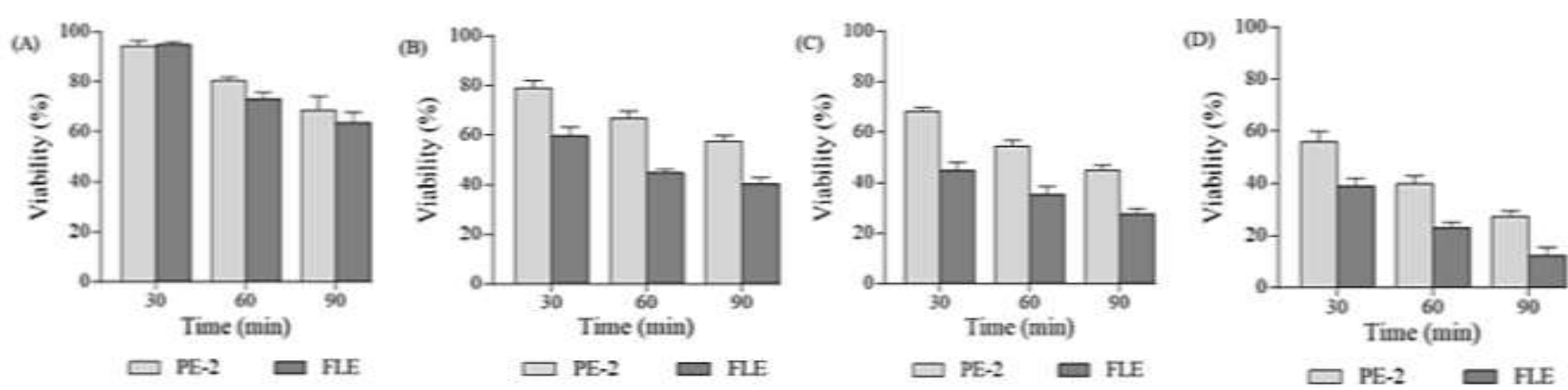

Control in (A) and concentrations of $2.0 \mu \mathrm{g} \mathrm{L}-1$ (B); $4.0 \mu \mathrm{g} \mathrm{L}-1$ (C) and $6.0 \mu \mathrm{g} \mathrm{L}{ }^{-1}$ (D). Source: Research data.

The results of this study are in line with the literature, especially with studies such as those by Vallejo et al. (2017), who carried out studies with the herbicide glufosinate using yeast and observed morphological changes such as round and large cells, which are typical alterations in the cell wall when interference occurs in the transport and absorption pathways of nutrients causing the loss of cell vitality. A similar answer was found by Bereketoglu et al. (2017), who using S. cerevisiae 
BY4742 and concentrations of 1 to $5 \mathrm{mg} \mathrm{L}^{-1}$ of nonylphenol, observed that there was growth inhibition and changes in yeast gene expression.

In evaluating the growth profile of the PE-2 and FLE yeasts concerning the action of 2,4-D, it was observed that the yeasts suffered growth inhibition differently. Therefore, in a time of 30 minutes, both yeasts had growth in all concentrations analysed, in 60 minutes the yeast PE-2 showed mild growth inhibition and for FLE there was moderate inhibition, whereas in the time of 90 minutes PE-2 had moderate inhibition and severe FLE inhibition (Table 1). Possibly due to the time of exposure of the 2,4-D compound, there was a strong molecular interaction of the pesticide about the cell wall and membrane and consequently at the membrane level among other cellular structures, triggering severe inhibition in the growth of the FLE yeast.

However, studies using bioassays with S. cerevisiae, when exposed to pesticides, including diuron, dicamba, mecoprop, atrazine, terbutrin, acetamiprid, 2,4-D, showed a cytotoxic effect on yeast (Westlund \& Yargeau, 2017). In addition, transcriptional analysis studies reveal that the use of xenobiotic compounds act as a stressor and play a repressive effect on the TOR pathway, such pathway regulates numerous cellular mechanisms, such as cell homeostasis, nutrient assimilation, and signalling pathways responsible for maintaining cell integrity (Dobrenel et al., 2016).

Table 1. Evaluation of cell growth of the Pedra-2 and Fleischmann ${ }^{\circledR}$ strains in relation to 2,4-D pesticide concentrations in 30 , 60 and 90 minutes.

\begin{tabular}{|c|c|c|c|c|c|}
\hline \multirow{2}{*}{ Yeasts } & \multirow{2}{*}{ Time (min) } & \multicolumn{4}{|c|}{ Concentrations $\left(\mu \mathrm{g} \mathrm{L}^{-1}\right)$} \\
\hline & & Control & 2.0 & 4.0 & 6.0 \\
\hline Pedra-2 & & + & + & + & + \\
\hline Fleischmann® & & + & + & + & + \\
\hline Pedra-2 & 60 & + & ++ & ++ & ++ \\
\hline Fleischmann ${ }^{\circledR}$ & & + & +++ & +++ & +++ \\
\hline Pedra-2 & 90 & + & ++++ & ++++ & ++++ \\
\hline Fleischmann ${ }^{\circledR}$ & & + & ++++ & ++++ & ++++ \\
\hline
\end{tabular}

(+) growth, $(++)$ mild inhibition, $(+++)$ moderate inhibition, $(++++)$ severe inhibition. Source: Authors.

The use of the eukaryotic model can contribute to the understanding of the stressful effect of the presence of pesticides on human health and the environment. Given the fact that several signalling pathways and molecular structures are conserved among eukaryotic organisms, this model can be used to assess the consequences of chemical agents in the expression of fundamental pathways (O'Connor et al., 2013). Furthermore, changes in the genetic profile of organisms can provide a quick and sensitive response to the action of a toxic compound. Studies report that chemical compounds with analogous toxicological properties may have a gene expression characteristic of a "signature profile" (Smith, 2010).

In the analysis of the action of the 2,4-D compound on yeast cell growth, it was noted that there was a gradual growth inhibition at all concentrations and times analysed. However, this action was more effective in 90 minutes for the FLE yeast. PE-2 had a greater growth against the action of the compound, proving to be more resistant (Figure 3). Possibly yeast survival against toxic compounds is closely related to gene expression, causing changes in phenotype and aiming to maintain its cellular integrity. We can observe that the toxicity mechanism responds differently in S. cerevisiae, as observed in this study.

Bioassays using S. cerevisiae to analyze the toxicological action of pesticides are based on the analysis of changes in cell metabolism against toxic compounds (Régo et al., 2018). Furthermore, studies have shown that when S. cerevisiae was 
exposed to xenobiotic compounds, changes occurred in its intracellular mechanisms of repair, detoxification and cellular adaptation (Dragone et al., 2015).

Figure 3. Analysis of the cellular growth profile of Pedra-2 and Fleischmann® yeasts against 2,4-D pesticide concentrations.

\begin{tabular}{|c|c|c|c|c|c|}
\hline \multirow{2}{*}{ Time $(\mathrm{min})$} & \multirow{2}{*}{ Yeasts } & \multicolumn{4}{|c|}{ Concentrations $\left(\mu \mathrm{g} \mathrm{L}^{-1}\right)$} \\
\hline & & Control & 2.0 & 4.0 & 6.0 \\
\hline \multirow{2}{*}{30} & Pedra-2 & & & & \\
\hline & Fleischmann $\otimes$ & & & & \\
\hline \multirow{2}{*}{60} & Pedra-2 & & & & \\
\hline & Fleischmann $\otimes$ & & & & \\
\hline \multirow{2}{*}{90} & Pedra-2 & & & & \\
\hline & Fleischmann $\otimes$ & & & & \\
\hline
\end{tabular}

Source: Authors.

In the evaluation of the flocculation test, there were changes in the phenotype of the analysed yeasts. The data showed a greater cell-cell adhesion (flocculation) over time and with the increase in the concentration of the 2.4-D pesticide, notable that in the longer time (90 min) at the concentration of $6.0 \mu \mathrm{g} \mathrm{L}^{-1}$ the FLE yeast had a higher flocculation condition than the PE-2 yeast. The analysis and interpolation of the growing conditions indicate that this yeast response is possibly related to the nature and chemical structure of the compound, which possibly induced the activation of the gene interaction mechanism causing an increase in flocculation, such phenotype it is associated with induction of the FLO gene, responsible for the formation of floccules (Figure 4). Still, it can be inferred that the compound showed toxicity, as the flocculation mechanism in yeasts consists of a complex mechanism, such as gene expression causing gene activation (FLO), and which is responsible for this phenotype and that only are activated against stress factors as a form of self-protection.

For Goossens and Willaert (2010), this behaviour is extremely relevant when dealing with yeasts, as this defence mechanism makes it withstand adverse environmental conditions. Therefore, the action of pesticides on organisms can be strongly related to the variation of their chemical structure, exposure time and concentration (Dos Santos et al., 2012). S. cerevisiae has proven to be a magnificent eukaryotic model in evaluating cytotoxic effects concerning cellular responses to weak acids used as pharmaceuticals or pesticides (Lazard et al., 2017; Eki, 2018). The same authors point out that although there are not numerous peculiar targets for drugs and pesticides in yeast, the primary cellular mechanisms for resistance to chemical stress are similar with phylogenetically distant organisms, making it possible to supplant the information acquired in yeasts for higher eukaryotes. 
Furthermore, we can observe in this study that the flocculation mechanism in FLE yeast was more effective to time and concentration of pesticide, data that corroborate the literature. Therefore, bioassays using yeasts present advantages, for being easy to handle and for presenting fast and efficient physiological responses, such as flocculation mechanisms presented by the yeast FLE, dazzling to be an important microorganism to be used in environmental monitoring.

According to Rumlova and Dolezalova (2012), S. cerevisiae has proved to be a model microorganism for several experimental tests with great environmental importance to assess possible changes in the expression of genes related to environmental pollutants, especially with chemical and agricultural products. The 2,4-D compound is classified as extremely toxic, belonging to the class of herbicides widely used in numerous crops, which can cause toxicity and genotoxicity to live organisms and compromise natural resources (Sarabia et al., 2019), in addition to having a worldwide impact, pesticides can have specific effects on organisms as observed in this study, mainly in FLE yeast, affecting its growth. We can suggest that this compound has interacted with molecular mechanisms, causing growth inhibition, loss of viability and flocculation, such cellular responses are possibly related to the TOR pathway responsible for several cellular mechanisms in eukaryotes.

Figure 4. Flocculation profile of Pedra-2 and Fleischmann ${ }^{\circledR}$ yeasts at different concentrations of 2,4-D pesticide.

\begin{tabular}{|c|c|c|c|c|c|}
\hline \multirow{2}{*}{ Time (min) } & \multirow{2}{*}{ Yeasts } & \multicolumn{4}{|c|}{ Concentrations $\left(\mu \mathrm{g} \mathrm{L}^{-1}\right)$} \\
\hline & & Control & 2.0 & 4.0 & 6.0 \\
\hline \multirow{2}{*}{30} & Pedra-2 & & & & \\
\hline & Fleischmann $\mathbb{B}$ & & & & \\
\hline \multirow{2}{*}{60} & Pedra-2 & & & & \\
\hline & Fleischmann $\mathbb{B}$ & & & & \\
\hline \multirow{2}{*}{90} & Pedra-2 & & & & \\
\hline & Fleischmann ( & & & & \\
\hline
\end{tabular}

Source: Authors.

\section{Conclusion}

The FLE yeast showed greater phenotypic changes compared to the PE-2 strain in the interaction with 2,4-D pesticide. In cell viability both yeasts suffered a loss of viability against the compound, however, the FLE strain showed greater sensitivity about growth and cell flocculation mechanisms.

The toxicity tests carried out in this study showed the toxicity action of the 2,4-D pesticide in the analyzed yeasts and that the action of the compound was more impactful for the FLE strain, thus demonstrating the potential of this microorganism 
as an important biological marker. Thus, we can suggest that this microorganism can be used as a bioindicator for environmental analysis.

However, further studies are needed using more robust methodologies, such as physiological, genomic, protons, among others, which will ensure the characterisation and identification of responses to toxic agents in the environment.

\section{Acknowledgments}

This study was financed in part by the Coordenação de Aperfeiçoamento de Pessoal de Nível Superior - Brasil (CAPES) - Finance Code 001"for MSM; DTS and LPM and the Conselho Nacional de Desenvolvimento Científico e Tecnológico (CNPq)

\section{Reference}

Bereketoglu, C., Nacar, G., Sari, T., Mertoglu, B., \& Pradhan, A. (2021). Transcriptomic analysis of nonylphenol effect on Saccharomyces cerevisiae. PeerJ, 9, e10794.

Carvalho, F. P. (2017). Pesticides, environment, and food safety. Food and Energy Security, 6(2), 48-60.

da Silva Pinto, T. J., Moreira, R. A., da Silva, L. C. M., Yoshii, M. P. C., Goulart, B. V., Fraga, P. D., Rolim, V. L. S., Montagner, C. C., Daam, M. A., \& Espindola, E. L. G. (2021). Toxicity of fipronil and 2, 4-D formulations (alone and in a mixture) to the tropical amphipod Hyalella meinerti. Environmental Science and Pollution Research, 1-14.

Dobrenel, T., Caldana, C., Hanson, J., Robaglia, C., Vincentz, M., Veit, B., \& Meyer, C. (2016). TOR signaling and nutrient sensing. Annual review of plant biology, 67, 261-285.

Dos Santos, S. C., Teixeira, M. C., Cabrito, T. R., \& Sá-Correia, I. (2012). Yeast toxicogenomics: genome-wide responses to chemical stresses with impact in environmental health, pharmacology, and biotechnology. Frontiers in genetics, 3, 63.

Dragone, R., Cheng, R., Grasso, G., \& Frazzoli, C. (2015). Diuron in water: Functional toxicity and intracellular detoxification patterns of active concentrations assayed in tandem by a yeast-based probe. International journal of environmental research and public health, 12(4), 3731-3740.

Francisco, W. C., \& Queiroz, T. M. D. (2018). Biorremediação. Nucleus, 15(1), 249.

Goossens, K., \& Willaert, R. (2010). Flocculation protein structure and cell-cell adhesion mechanism in Saccharomyces cerevisiae. Biotechnology letters, 32(11), 1571-1585.

Grasso, G., Caracciolo, L., Cocco, G., Frazzoli, C., \& Dragone, R. (2018). Towards simazine monitoring in agro-zootechnical productions: A yeast cell bioprobe for real samples screening. Biosensors, $8(4), 112$.

Hagler, A. N. (2006). Yeasts as indicators of environmental quality. In Biodiversity and ecophysiology of yeasts (pp. 515-532). Springer, Berlin, Heidelberg.

Lee, S. S., Robinson, F. M., \& Wang, H. Y. (1981). Rapid determination of yeast viability. In Biotechnol. Bioeng. Symp., (United States) (Vol. 11, No. CONF810554-). Univ. of Michigan, Ann Arbor.

Lopes, M. L., Paulillo, S. C. D. L., Godoy, A., Cherubin, R. A., Lorenzi, M. S., Giometti, F. H. C., Bernardino, C. D., Amorim Neto, H. B., \& Amorim, H. V. D. (2016). Ethanol production in Brazil: a bridge between science and industry. Brazilian Journal of Microbiology, $47,64-76$.

Régo, A. P. J., Mendes, K. F., Bidoia, E. D., \& Tornisielo, V. L. (2018). Effects of ametryn on mutagenicity (Tradescantia pallida) and cell viability (Saccharomyces cerevisiae). Brazilian Journal of Technology, 1(2), 288-296.

Miorin, J. D., Camponogara, S., Dias, G. L., da Silva, N. M., \& Viero, C. M. (2016). Percepções de agricultores sobre o impacto dos agrotóxicos para a saúde e o meio ambiente. Revista de Enfermagem do Centro-Oeste Mineiro, 6(3).

Moreno-García, J., García-Martinez, T., Moreno, J., Mauricio, J. C., Ogawa, M., Luong, P., \& Bisson, L. F. (2018). Impact of yeast flocculation and biofilm formation on yeast-fungus coadhesion in a novel immobilization system. American Journal of Enology and Viticulture, 69(3), $278-288$.

Noel, S. (2015). Economics of Land Degradation Initiative: Report for policy and decision makers_ Reaping economic and environmental benefits from sustainable land management. Bonn, Germany: ELD Initiative and Deutsche Gesellschaft für Internationale Zusammenarbeit (GIZ) GmbH.

North, M., \& Vulpe, C. D. (2010). Functional toxicogenomics: mechanism-centered toxicology. International journal of molecular sciences, 11(12), 47964813 .

O'Connor, S. T. F., Lan, J., North, M., Loguinov, A., Zhang, L., Smith, M. T., Gu, A. Z., \& Vulpe, C. (2013). Genome-wide functional and stress response profiling reveals toxic mechanism and genes required for tolerance to benzo [a] pyrene in $\mathrm{S}$. cerevisiae. Frontiers in genetics, $3,316$.

Rumlova, L., \& Dolezalova, J. (2012). A new biological test utilising the yeast Saccharomyces cerevisiae for the rapid detection of toxic substances in water. Environmental toxicology and pharmacology, 33(3), 459-464. 
Research, Society and Development, v. 10, n. 11, e408101119912, 2021

(CC BY 4.0) | ISSN 2525-3409 | DOI: http://dx.doi.org/10.33448/rsd-v10i11.19912

Sarabia, D. T., Mueller, L. P., Mascarenhas Santos, M. S., Batistote, M. E., \& Júnior, R. P. S. (2019) O panorama da utilização de agrotóxicos no Brasil. Educação Ambiental em Ação, 68, 01-12.

Sissino, C., \& Olveira-Filho, E. C. (2013). Princípios de toxicologia ambiental: conceitos e aplicações. Rio de Janeiro: Interciência.

Smith, A. M., Ammar, R., Nislow, C., \& Giaever, G. (2010). A survey of yeast genomic assays for drug and target discovery. Pharmacology \& therapeutics, 127(2), 156-164.

Teixeira, M. C., Duque, P., \& Sa-Correia, I. (2007). Environmental genomics: mechanistic insights into toxicity of and resistance to the herbicide 2, 4D. Trends in Biotechnology, 25(8), 363-370.

Thomaz, T. O uso do 2,4 D e seu papel na Agricultura, 2018. Revista Cultivar. https://www.grupocultivar.com.br/noticias/o-uso-do-2-4-d-e-seu-papel-na agricultura.

Vallejo, B., Picazo, C., Orozco, H., Matallana, E., \& Aranda, A. (2017). Herbicide glufosinate inhibits yeast growth and extends longevity during wine fermentation. Scientific reports, 7(1), 1-10.

Westlund, P., \& Yargeau, V. (2017). Investigation of the presence and endocrine activities of pesticides found in wastewater effluent using yeast-based bioassays. Science of the Total Environment, 607, 744-751. 